\title{
BK Virus Infection
}

National Cancer Institute

\section{Source}

National Cancer Institute. BK Virus Infection. NCI Thesaurus. Code C123276.

An infection caused by the BK virus. It usually causes an asymptomatic infection, except

in immunocompromised individuals where it may cause nephropathy or hemorrhagic cystitis. 